\title{
Craft Entry for Minorities: The Case of Project JUSTICE
}

\author{
David B. Lipsky
}

Cornell University

Joseph B. Rose

University of New Brunswick at Fredrickton 
Craft Entry for Minorities: The

Case of Project JUSTICE, 2

Demonstrations in Chicago and Pittsburgh in 1969 focused national attention on the problem of the racial integration of the building trades. ${ }^{1}$ Many solutions to the problem have been suggested or tried, including efforts to create equal opportunities for blacks in apprenticeship programs. ${ }^{2}$ But apprenticeship programs provide only a limited means of entry to the building trades. Most construction workers who attain journeyman status do so through informal means. ${ }^{3}$ As Quinn Mills has observed, "Integration of the building trades will be necessarily slow if it is accomplished only through indenturing apprentices. . . National policy regarding integration of the trades should concern itself with informal routes of entry as well as with apprenticeship." 4

One pioneering effort in this direction was Project JUSTICE (Journeymen Under Specific Training in Construction Employment) in Buffalo, New York. ${ }^{5}$ The goal of JUSTICE was to make craft journeymen of adult blacks by means of classroom instruction and on-the-job training. ${ }^{6}$

${ }^{1}$ For background information on the question of the racial integration of the building trades, see $\mathrm{F}$. Ra Marshall and Vernon M. Briggs, Jr., The Negro and Apprenticeship (Baltimore: Johns Hopkins Press, 1967).

${ }^{2}$ Ibid. See also F. Ray Marshall and Vernon M. Briggs, Jr., Equal Apprenticeship Opportunities: The Nature of the Issue and the New York Experience (Washington, D. C.: Institute of Labor and Industrial Relations, University of Michigan-Wayne State University and the National Manpower Policy Task Force, 1968) and George Strauss and Sidney Ingerman, "Public Policy and Discrimination in Apprenticeship," Hastings Law Journal, XVI (February, 1965), 285431.

${ }^{3}$ George Strauss, "Apprenticeship: An Evaluation of the Need," in Arthur M. Ross, editor, Employment Policy and the Labor Market (Berkeley and Los Angeles: University of California Press, 1965), pp. 299-332.

${ }^{4}$ Quinn Mills, "Discussion," in Peter B. Doeringer, editor, Programs to Employ the Disadvantaged (Engelwood Cliffs, N.J.: Prentice-Hall, 1969), p. 205.

${ }^{5}$ Reference is made to USTICE in Edward C. Pinkus, "The Workers' Defense League," in Doeringer, op. cit., p. 1971 See also Construction Labor Report, July 3, 1968, for a description of the program.

${ }^{6}$ We would like to thank John E. Drotning and Howard G. Foster for their assistance in preparing this report on Project JUSTICE. We owe a particular debt of gratitude to David Coins, Director of the Joint Apprenticeship Program in Buffalo, for his cooperation. 
Craft Entry for Minorities: The Case of Project JUSTICE, 3

The Buffalo press described the project as the "first in the nation."7 Classroom training began early in May 1968, and shortly thereafter the Labor Department agreed to finance the project with $\$ 114,225$. Indeed, Project JUSTICE was one of the first, if not the first minority training program in construction which by-passed apprenticeship and instead provided short term training which would presumably lead directly to journeyman status after only nine weeks in class and 20 on the job. In a sense, Project JUSTICE was both a success and a failure. It was a success because 40 of the 50 men who were permitted to enter the program completed their seven months of training and 25 out of the 27 men permitted to take their journeyman qualification test passed it. It was a failure because the program was terminated in the midst of a major controversy partly revolving around the construction of a new State University campus in Buffalo. At this writing, tensions in Buffalo between the minority community and the building trades continue to mount, and the problem of the integration of the Buffalo building trades has yet to be solved.

There has been growing recognition of the need for special journeyman training programs in the construction industry as a means of expediting integration. Blacks who are above apprenticeship age limitations (usually 26 or 27) find it particularly difficult to acquire the skills needed to become journeymen. The unions themselves have recognized the need for journeyman training. The Building Trades Department accepted the concept in 1968 in an

\footnotetext{
${ }^{7}$ Buffalo Evening News, May 21, 1968 p. 14.
} 
Craft Entry for Minorities: The Case of Project JUSTICE, 4

agreement with the Department of Labor for the Model Cities Program. ${ }^{8}$ Journeyman training programs have been begun in Baltimore, Oakland, Boston, St. Louis, and Washington, D.C., and are in the planning stages for at least a dozen other cities. ${ }^{9}$

Although JUSTICE was only a small pilot project, it seems worthwhile to evaluate its short and stormy existence carefully, especially if it is to eventually serve as a model for national policy.

\section{Design of Project JUSTICE}

The novelty of Project JUSTICE was its attempt to recruit black workers above the normal apprentice-able age and, within the space of 29 weeks of classroom and on-the-job training, move them into full journeyman status in the building trades. The project was the brainchild principally of the Workers' Defense League and the Opportunities Development Corporation (ODC), a local nonprofit corporation with extensive experience in sponsoring manpower training programs in the Buffalo area. ${ }^{10}$ The Buffalo Building and Construction Trades Council and the Construction Industry Employers Association cooperated in planning the venture, helping to develop a proposal which was submitted to the Department of Labor for financing in the spring of 1968.

${ }^{8}$ See Construction Labor Report, July 17, 1968, and the statement "Policy Guidelines on Model Cities Agreements Adopted by the AFL-CIO Building Trades Department."

${ }^{9}$ Manpower Report of the President, 1970, p. 98.

10 John E. Drotning, David B. Lipsky, and Myron D. Fottler, Jobs, Education, and Training: Research on a Project Combining Literacy and On-the-Job Training for the Disadvantaged, Final Report submitted to the Office of Manpower Research, US Department of Labor, April, 1971. 
Craft Entry for Minorities: The Case of Project JUSTICE, 5

The contractors and unions were prompted to support this new training effort by the necessity of developing affirmative action plans required by the Office of Federal Contract Compliance for federally supported construction projects. ${ }^{11}$ The employers and unions believed that by sponsoring JUSTICE, "preaward conference, manning tables, etc., on a project basis would become only a formality."12

Trainees were recruited by a committee consisting of union, contractor, and minority group representatives. JUSTICE officials believed that the program could produce full-fledged journeymen in a relatively short period of time, provided that the trainees recruited had already acquired mechanical skills and aptitudes through successful work experience, preferably in construction itself. (None of the trainees had ever worked in unionized construction, however.)

During the first nine weeks, the trainees received classroom instruction three nights a week. During this period all men continued to hold their old jobs. A substantial majority (31) were employed as craftsmen and operatives, nine were employed in white-collar jobs, and the rest in other blue-collar occupations. Most of the trainees were employed in manufacturing or the services, but five held jobs in (nonunion) construction. The trainees were averaging \$2.78

11 "Affirmative action" is required by Section 202(1) of Executive Order 11246 issued by President Johnson in 1885. See Michael 1. Sovern, Legal Restraints on Racial Discrimination in Employment (New York: Twentieth Century Fund, 1966), pp. 103-142. The test of E.O. 11248 is contained in Sovern, Appendix B, pp. 227-234. E.O. 11246 forms the legal basis for the "Philadelphia Plan." See US. Senate Hearings on the Philadelphia Plan Before the Subcommittee on the Separation of Powers of the Committee on the Judiciary, 91st Cong., 1st sess.

(Washington, D.C.: Government Printing Office, 1970) wherein the text of the revised Philadelphia Plan is printed, pp. 28-38.

12 “Affirmative Action Program, Buffalo-Western New York Area, Phase 111, Project JUSTICE journeyman Trainee Program," n.a., n.d. This was the program prospectus written for the Department of Labor. 
Craft Entry for Minorities: The Case of Project JUSTICE, 6

an hour on their current jobs. By becoming journeymen, they faced the pleasant prospect of doubling their average hourly wage rate.

The first three weeks of classroom training were devoted to a broad indoctrination of the trainee to construction employment, as well as basic instruction in math, blueprint reading, and related skills. At the end of this period the trainees were assigned to specific trades and for the next six weeks received practical skill instruction and "craft relevant academics" in their trade.

At the conclusion of classroom instruction the trainees entered into 20 weeks of on-thejob training in their craft. Those trainees who completed the course became eligible to take the trade's journeyman qualification exam. Those who passed were to receive their union card. Although it was hoped that all those who completed the course would qualify for the exam, provision was made for an additional period of OJT for those who did not qualify but still showed continuing potential. Those who showed no potential whatsoever were to be terminated from the program.

Insert Table 1 Here

One of the really innovative and unusual features of Project JUSTICE was the creation of a new job classification called "journeyman trainee." It was agreed by the unions and contractors that JUSTICE trainees would receive the wage rate established for card-carrying journeymen in the craft for which the trainee was undergoing instruction. It is reported that 
some journeymen as well as apprentices working at lower apprentice wage rates objected to this policy. The authors have not been able to find other instances of journeyman training programs which included this feature.

Initially the program was set up to provide training slots for only 50 workers. Buffalo had, at the time, a construction workforce of nearly 10,000 journeymen. Obviously a smallscale program of this type could hardly be expected to satisfy completely the OFCC's affirmative action requirements. However, the founders of the program envisaged JUSTICE, once it was firmly established, becoming a permanent institution in Buffalo and a major port of entry for black workers into the construction industry.

\section{Program Outcome}

Table 1 traces what happened to the trainees in the course of their training. Four dropped out within the first few weeks of classroom training. Another six were lost during the 0 JT period. Thus, 40 trainees were available for the journeyman examination. A graduation ceremony was held at the conclusion of the OJT period, and certificates were awarded to the men. The executive director of ODC told them, "You are seeing history being made in the United States-right now!" He indicated that an expanded program to train up to 150 men was in the planning stages, with a beginning date of March 1969. ${ }^{13}$ Peter Brennan, president of the New York State Building Trades Council, characterized the program as "a great breakthrough." ${ }^{14}$

\footnotetext{
${ }^{13}$ Buffalo Evening News, November 18, 1908, p. 12.

${ }^{14} \mathrm{Ibid}$.
} 
Craft Entry for Minorities: The Case of Project JUSTICE, 8

Exactly how one characterizes what happened next is a matter of some controversy. The basic facts are fairly clear, however. Only 27 of the 40 "graduates" were permitted by the unions to take the journeyman examination. (Two failed and the rest passed.) JUSTICE officials claimed a breach of faith by the building trades unions. The unions countered by describing the 13 who were not permitted to take an examination as "not qualified." Part of the controversy centered on whether any of the 13 should be recycled into another 20 weeks of on-the-job training. The unions felt a few could be recycled and the rest dropped, while JUSTICE officials believed all 13 trainees should have been given the qualifying exam in the fist place. ${ }^{15}$ Six of the rebuffed trainees filed court suits claiming that they were inequitably denied the opportunity to take an examination.

\section{Program Environment and Ramifications}

To understand why JUSTICE, begun in an aura of hope, ended in an atmosphere of bitterness on all sides, one has to know something about the events that were developing concurrently in the Buffalo area. While JUSTICE trainees were still undergoing on-the-job training, Governor Nelson Rockefeller came to Buffalo to break ground for a new campus of the State University of New York at Buffalo. To be built on a 1,200-acre site in suburban Amherst,

\footnotetext{
${ }^{15}$ It should be emphasized that the unions determined who was qualified to take the journeyman examination. The fact that 40 trainees had satisfactorily completed the OJT portion of the JUSTICE program far exceeded the expectations of the unions. It appears that the unions simply prohibited some trainees from taking the exam and discouraged others with efforts to recycle them for additional training. In at least one instance a trainee scheduled for recycling was unable to obtain work.
} 
Craft Entry for Minorities: The Case of Project JUSTICE, 9

the campus was estimated to cost $\$ 650$ million and to provide thousands of new construction jobs over a period of several years.

Almost immediately these contemplated jobs became the subject of social concern and political maneuvering. Representatives of the minority community demanded that the work force on the new campus be completely integrated. They soon found willing allies among some of the 20,000 students at the University. Local union officials found themselves being castigated for their alleged racist policies. The fact that they had helped sponsor JUSTICE, cooperated with the Workers' Defense League, and made related efforts to solve the industry's racial problem appeared to the critics as mere tokenism.

Although university officials and state administrators moved to stave off the looming crisis, their efforts provided ineffective, and ultimate confrontation became a near certainty. It was in this atmosphere that JUSTICE trainees approached their qualifying exams. The unions, reluctant partners initially, now became resentful and hostile. They felt they had dealt in good faith with the minority community and had received unwarranted abuse in return. The problem was complicated by the factionalism of the minority groups. None of the parties then, or indeed in the next three years, knew exactly who spoke for the minority workers.

Thus, the JUSTICE program was terminated in the midst of internecine quarreling between the minority community and the construction unions. No new trainees were ever entered into the program, as had been planned, nor were any of those not permitted to take the qualifying exam recycled for further training. To outside observers, Project JUSTICE appeared a failure. It did not succeed in breaking down ancient antagonisms and mistrust, or in 
Craft Entry for Minorities: The Case of Project JUSTICE, 10

overcoming in any meaningful way traditional patterns of discrimination in the building trades. It did not prove to be the answer to the contractors' need for an effective affirmative action plan in western New York.

Indeed, JUSTICE proved to be only the opening round of a battle which mounted steadily over the next two years, gaining national attention. ${ }^{16}$ Angry blacks and Puerto Ricans mounted demonstrations, and were joined by students at the University. Early in 1969 students overturned construction shacks during demonstrations on the old Buffalo campus. The prospect for more violent action caused Governor Rockefeller to declare a moratorium on the construction of a new campus in March 1969. All building was halted for nearly a year while the Governor attempted to work out an agreement between the black community and the unions and contractors.

In February 1970 the Governor announced that he had succeeded in obtaining an effective affirmative action plan and that he would resume construction of the new campus. Unfortunately, this did not spell the end of the controversy. Although building did resume, minority groups remained unsatisfied with a plan they felt had been dictated by the Governor. Suffice it to say that at this writing the situation remains unsettled.

While Buffalo continues to grapple with its problem of black employment in construction, JUSTICE officials remain convinced that they had found at least part of an

\footnotetext{
${ }^{16}$ See the feature article in the New York Times, September 18, 1970, $39 \mathrm{ff}$. The article is entitled, "Two Years of Racial Protest Stall Buffalo Campus Project." See also New York Times, August 20, 1970, p. 28.
} 
effective solution to the problem. To outsiders JUSTICE appears to have been just another disappointment in a long line of dashed hopes. But JUSTICE officials believe their program's basic concept was proven correct and workable. It is possible, in their opinion, to recruit black workers of quality and, by upgrading their skills, to make them construction journeymen in a relatively short period of time. According to JUSTICE officials, only the unions' intransigent attitudes stood in the way of complete success. In any event, 25 black workers did receive their union cards and obtained fairly regular employment in construction thereafter.

\section{Factors Related to the Success of JUSTICE Trainees}

Were there any observable factors which distinguished the 25 "successful" JUSTICE trainees from the 25 who were "unsuccessful"? Did the workers who ultimately gained entry into the trades possess higher levels of education, training, and experience than those who were not permitted to take the journeyman's exam and those who dropped out?

It is well to keep in mind that the JUSTICE trainees were carefully selected so as to maximize their chance of success in the program. They can by no means be characterized as "disadvantaged" in terms of their prior education, training, and work experience. The trainees were adult heads of households and averaged three dependents apiece. Their mean age was 33.7 years and the range was from 25 to 49 . Their average level of formal education was 11.5 years. In fact, nine trainees had completed at least one year of college, and one trainee had completed three years of college. 
Craft Entry for Minorities: The Case of Project JUSTICE, 12

Thirty-four trainees (68 per cent) had once before been involved in some type of formal training program. Twenty-three received prior training in the military, nine in vocational schools, and two at the local community college. A majority of JUSTICE trainees (36) possessed at least one general ability related to construction. The most widely possessed skill was blueprint reading (28 trainees), followed by ability to use the slide rule (15) and understanding layouts (13). Drafting, welding, and use of survey equipment were among the other skills possessed by the trainees. Nearly half (24) of the trainees possessed two or more of these general abilities, and two trainees possessed as many as four.

Of the 25 trainees who obtained union cards, five were carpenters, four were cement masons, three were bricklayers, and two each were electricians, painters, sprinkler fitters, and tile, marble, and terrazo workers. Each of five other trades accepted one new journeyman. On the other hand, a number of trades were completely unrepresented, e.g., the boilermakers, operating engineers, steamfitters, and asbestos workers. ${ }^{17}$

Did this pattern of acceptance merely reflect the relative abilities of the JUSTICE trainees, or was it principally related to the prevailing pattern of racial integration among the crafts? The following analysis suggests that the latter alternative is more nearly correct.

\footnotetext{
${ }^{17}$ Among those unions that did not issue union cards to trainees were two whose business agents served as the President and Secretary of the Buffalo Building and Construction Trades Council.
} 
Craft Entry for Minorities: The

Case of Project JUSTICE, 13

\section{Education, Training, and Skills}

We first examined the impact of formal education, training, and skills on trainee success. The most important result revealed that those trainees who had completed at least one year of college were significantly more successful than high school graduates and dropouts. The relation between skills acquired in prior training and trainee success did show that those trainees who acquired construction skills through prior training were more likely to have received a union card than those who acquired non-construction skills or received no prior training.

On the other hand, no relationship was evident between the possession of specific construction skills acquired outside of training programs and trainee success. Interpreting this result is difficult, however, since there is no way of determining the exact extent to which the trainees actually possessed these skills or of differentiating degrees of competence between trainees. But, since there was minimal overlap between the skill measures, they were treated as different measures of the trainees' capabilities.

\section{Employment Experience}

It is reasonable to hypothesize a relationship between a trainee's past employment experience and success in gaining craft entry and construction employment. One might expect, for example, that trainees who had been employed in high-paying, blue-collar jobs would have a greater chance of success than others. Certainly past employment in construction would seem to be a likely determinant of success. However, we discovered. Among those unions that 
Craft Entry for Minorities: The Case of Project JUSTICE, 14

did not issue union cards to trainees were two whose business agents served as the President and Secretary of the Buffalo Building and Construction Trades Council.

Delving further into the trainees' employment history, an attempt was made to demonstrate a possible relationship between trainee success and the number of prior jobs held related to but outside of construction. A job "related to construction" includes those in which a trainee's work had utilized skills such as industrial wiring, painting, structural design, etc. But the number of prior construction-related jobs was not significantly related to the success criterion. (This insignificance may, however, be a result of our rather crude approximation of "construction-related jobs.") An examination of the relation between the number of actual jobs held by trainees in the construction industry and success was also insignificant.

\section{Minority Composition of the Trades}

Finally, we tested the relation between trainee success and the racial composition of the Buffalo building trades. Two indices of racial composition have been utilized: (1) the number of black journeymen, and (2) the number of minority group journeymen (blacks, Puerto Ricans, and Indians), to the total number of journeymen. ${ }^{18}$

Our data show that there is a highly significant relation between the dependent variable (trainee success) and the racial makeup of the construction trades in Buffalo. In fact, the racial

\footnotetext{
18 18Information regarding the racial composition of the Buffalo construction trades was obtained from a 1967 survey conducted by the New York State Division of Human Rights.
} 
composition of the trades proves to be more strongly related to trainee success than any of the other variables we examined. As Table 2 shows, 86 per cent of those assigned to trades that already had a "fair share" (i.e., more than 1 per cent) of blacks ultimately obtained a union card, while only 26 per cent and 47 per cent of those assigned to all-white or nearly-all-white unions respectively gained entry. The high mechanical trades remained virtually unaffected by JUSTICE. Perhaps this result is not very surprising. But consider its full meaning: here was a program specifically designed to overcome past patterns of exclusion in the trades, and yet it obviously did not overcome these patterns. Despite the fact that JUSTICE initially solicited the cooperation and support of the unions, it did not really break down traditional barriers-at best, it simply lowered them a bit.

Insert Table 2 Here

While it is perhaps gratifying that JUSTICE succeeded in getting even a handful of trainees into several unions that had never before included a black face, it is on the whole disheartening that even a token program, well-conceived and executed, could do so little to overcome the reservoir of craft resistance to racial integration.

\section{Conclusion}

In summary, we discovered very little relation between a trainee's education, training, and past work experience and his chance of becoming a construction journeyman. To a limited 
Craft Entry for Minorities: The Case of Project JUSTICE, 16

extent the more qualified trainees fared better, but the major determinant of trainee "success" appears to be related principally to the prevailing pattern of craft integration. A major disappointment of the Buffalo experience is that six of ten unions previously lily-white still retain their all-white composition; these include the Asbestos Workers, Elevator Constructors, Lathers, Operating Engineers, Plasterers, and Steam Fitters. Of course, there may be other factors not examined here which might have played a critical role in determining trainee success, e.g., the attitudes and motivations of the trainees may well have affected their chance of attaining journeyman status. Further, it should be pointed out that measures of skill more sophisticated than those employed here might easily show a stronger relation to trainee success.

JUSTICE, like the Workers' Defense League and other "outreach" programs, provided no fundamental change in the industrial relations system of the construction industry. It played by the established rules of the game, with the training, hiring, and placement process still left largely to the unions. Attainment of journeyman status in the Buffalo trades is still largely an informal process. The attempt by JUSTICE to add some "formality" to the process for the sake of opening construction jobs for blacks, served, in the end, only to help polarize attitudes and perpetuate barriers to the further integration of the Buffalo trades.

Would the JUSTICE story have had a different outcome had concurrent events in Buffalo taken a different course? Of course, one can never know the answer for certain. However, we suspect that the outcome would have been similar even in the absence of the bitter imbroglio surrounding the new State University campus. Across the nation similarly conceived plans have 
Craft Entry for Minorities: The Case of Project JUSTICE, 17

fared no better. ${ }^{19}$ While minorities feel an increasing sense of frustration, union leaders feel their traditional prerogatives-and hence the very existence of their unions-threatened by precipitant policies. Unless and until policy makers can reconcile the apparently conflicting goals of racial integration and union job control, the struggle in the construction industry is likely to continue, and programs such as JUSTICE are not likely to thrive.

${ }^{19}$ A senior official of the Department of Labor recently told one of the authors in confidence that the government had given up on "home town solutions" as a means of achieving affirmative action in the construction industry. 
Craft Entry for Minorities: The Case of Project JUSTICE, 18

TABLE 1

\begin{tabular}{lc}
\hline \multicolumn{1}{c}{ The Disposition of JUSTICE Trainezs } \\
\hline $\begin{array}{l}\text { Completed training and passed journeyman } \\
\text { exam for union card }\end{array}$ & Number \\
$\begin{array}{l}\text { Completed training, but not permitted to } \\
\text { take journeymen exam } \\
\text { Completed training and failed journeyman exam }\end{array}$ & 25 \\
Dropped out during classroom instruction & 23 \\
Dropped out during on-the-job training & 4 \\
Total number trainees entering program & 6 \\
\hline
\end{tabular}


Craft Entry for Minorities: The Case of Project JUSTICE, 19

TABLE 2

Trannee Success and Percentage of Black AND MinORTTY JOURNEYMEN

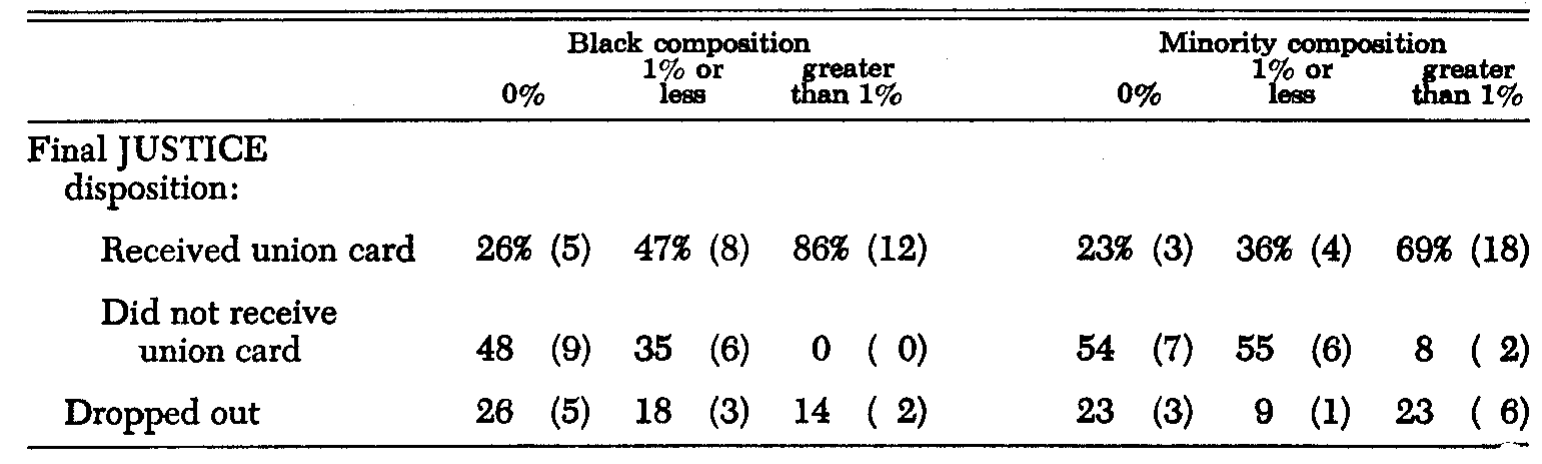

